\title{
Determinants of Households' Market Participation around Community Milk Cooling Plants, Western Kenya
}

\author{
Justus I. Emukule ${ }^{1}$, Mary J. Kipsat ${ }^{1} \&$ Caroline C. Wambui ${ }^{2}$ \\ ${ }^{1}$ Department of Agricultural Economics and Rural Development, Maseno University, Maseno, Kenya \\ ${ }^{2}$ Department of Animal Science, Maseno University, Maseno, Kenya \\ Correspondence: Justus I. Emukule, Department of Agricultural Economics and Rural Development, Maseno \\ University, Maseno, Kenya. Tel: 254-721-300-964. E-mail: emukulej2014@gmail.com
}

Received: November 7, 2017

Accepted: January 22, 2018

Online Published: February 15, 2018

doi:10.5539/jas.v10n3p204

URL: https://doi.org/10.5539/jas.v10n3p204

\begin{abstract}
Market participation in sub-Saharan Africa has been assessed mainly based on already producing households by looking at whether they sold or not, and if they sold, what quantities. The objective of this study was to determine the socio economic factors that influenced households' decisions on market participation in terms of dairy cow ownership and quantity of milk sold while taking into consideration the non-producers using Heckman two stage model. The model allowed for not only determination of the effects of household characteristics on volume of milk surplus sold by already producing households but also drew inferences on the effect of household characteristics on probabilities of dairy cow ownership whileadding new information to literature by generating the truncation effect. A multistage sampling technique was used to select 544 producer and non-producer households and primary data collected using a semi structured interview schedule through personal interviews. From the results, probit marginal effects for dairy cow ownership were associated positively and statistically significant with household size, the level of education and land size owned by the households. The Heckman selection estimates revealed that increased number of dairy cows per household positively influenced the volumes of milk sold, while household size influenced negatively the quantity of milk sold. In conclusion, milk sales conditional on dairy cow ownership suffered from negative selectivity bias whereby a household with sample average characteristics who selected into dairy cow ownership secured $40 \%$ lower quantity of milk sold than would a household drawn at random.
\end{abstract}

Keywords: community cooling plant, dairy cow ownership, heckman model, market participation, milk sales, truncation effect

\section{Introduction}

The dairy industry in Kenya is the single largest agricultural sub-sector (Muriuki et al., 2004). It contributes 14 percent of agricultural Gross Domestic Product (GDP) and 3.5 percent of total GDP (Government of Kenya [GoK], 2008). Milk production in Kenya is predominantly by small scale farmers who own one to three dairy animals, and produce about 80 percent of the milk in the country (Wambugu, Kirimi, \& Opiyo, 2011). The dairy industry statistics estimated that national annual milk production in 2012 stood at 3.73 billion litres (Kenya Dairy Board [KDB], 2012). Despite its contribution to the GDP, milk production and marketing are limited by several factors which include inadequate quantity of feed and poor road infrastructure respectively, (Wambugu et al., 2011). To address the issues on marketing, processors in the recent past made efforts to stimulate milk marketing by opening-up of milk catchment areas by establishing cooling and bulking centers. To supplement these efforts, donor projects and community initiatives also established more cooling plants within the same period.

In Western Kenya, several milk cooling plants were constructed and equipped between 2008-2016 for communities through joint funding of the World Bank and the Government of Kenya through a project called Western Kenya Community Driven Development and Flood Mitigation Project (WKCDDFMP). Nine of these community cooling plants were in the selected counties of study and started serving as market outlets for the milk produced by farmers. A recent study done in Western Kenya by Wanjala, Njehia, and Murithi (2015) revealed that utilization of the milk cooling plants' capacity stood at an average of $8.8 \%$ and only $8.6 \%$ of the initially registered farmers participated. In order to understand the reasons behind this trend, this study aimed at determining the socio economic factors that influenced households' decisions on market participation in terms of 
dairy cow ownership and quantity of milk sold around community milk cooling plants so as to inform appropriate policy interventions.

\section{Review of Empirical Framework on Market Participation}

Heltberg and Tarp (2002) emphasized that participation in agricultural markets by rural households was an important strategy for poverty alleviation and food security in developing countries. While investigating household discrete decision on whether to participate in coarse grain market, Goetz (1992) used a double hurdle approach to separate producing households into market participants (buyers and sellers) and autarkic non participants using probit in the first stage and switching regression for quantities bought and sold in the second stage. In their study on livestock market participation among pastoralists in Northern Kenya and South Ethiopia, Bellemare and Barret (2006) separated producers into net buyers, autarkic and net sellers using an ordered probit model for the first stage and two truncated normal models for net quantities bought and sold in the second stage.

Also Holloway, Barret, and Ehui (2001) used the double hurdle model to investigate the decision to participate in the milk market and decision of how much milk to supply in the market by Ethiopian dairy farmers near Addis Ababa. The results in this later study showed that quantity of milk sold was enhanced by education levels and number of local and crossbreed cows owned by households. In all these studies undertaken, the investigations were based on the already producing households only. The limitation with that approach was that estimates of the determinants of market participation would be biased and not suitable for use in informing the sustainable design and evaluation of development projects aimed at increasing market participation among subpopulations that contained those who do not produce.

This study applied the Heckman two stage regression model to determine the socio economic factors that influenced households decisions on market participation in terms of dairy cow ownership and quantity of milk sold around community milk cooling plants.

\section{Methodology}

\subsection{The Study Area}

The areas of study comprised of two counties of Bungoma and Kakamega in Western Kenya where the Western Kenya Community Driven Development and Flood Mitigation Project activities were implemented. According to the 2009 population census report, Kakamega county had a population of 1,660,651, an area of $3033.8 \mathrm{~km}^{2}$ and $49 \%$ poverty level (GOK, 2014) while Bungoma County had a population of $1,375,063$ people, and an area of $2,069 \mathrm{~km}^{2}$ and $47 \%$ poverty level. In both areas the economy was mainly driven by agriculture, predominantly livestock, sugarcane and maize production.

\subsection{Sample Size and Sampling Techniques}

\subsubsection{Sample Size}

The formula: $n=K^{2} R(1-R) / D^{2}$ as given by Kothari (2004) was used to determine the sample size around each milk cooling plant. Where, $\mathrm{n}=$ sample size; $\mathrm{R}=$ Proportion of the population containing the major attribute (Dairy cow ownership); $\mathrm{D}=$ Margin of error in percentage; $\mathrm{K}=$ Confidence level (Z-value).

Without the prior knowledge of the proportion of producer households, $\mathrm{R}=0.5$, and confidence level of $95 \%, \mathrm{Z}=$ 1.96 , with $\mathrm{D}=0.1$. This gave sample sizes of 96 for each cooling plant. This size was upscaled to 136 for purposes of having sufficient numbers for analysis of the producers and non-producers.

\subsubsection{Sampling Techniques}

A multi stage sampling technique was used whereby the western region was divided into five counties. Two counties were randomly selected, each with 5 and 4 functional milk cooling plants respectively established through funding by the Western Kenya Community Driven Development and Flood Mitigation Project. Two cooling plants were selected in each county using simple random sampling. With the help of key informants around each community milk cooling plant, two lists were constituted from households who owned dairy cows and those who did not own any dairy cow. From each list, at least 68 households were selected by simple random sampling technique giving a total of 544 respondents.

\subsection{Data Collection}

Households' data collected included age of household head, gender of household head, education level, distance to the main market centre, wealth of the household and land acreage owned. For producers additional data collected included type and number of dairy cows owned, quantity of milk produced and marketed. 
A semi structured checklist was used to obtain the above information. Data collection was carried out in the period of April to May 2016 using personal interview method at the household level. Key informant interviews were conducted with the community milk cooling plants' management.

\subsection{Statistical Analysis}

\subsubsection{Theoretical Framework}

Heckman's two step procedure was used where the first step involved using a probit function (dairy cow ownership). Equation (1) was used to predict the probability that a given household will adopt a dairy cow:

$$
\operatorname{Pr}\left(\mathrm{z}_{\mathrm{i}=1} \mid \mathrm{w}_{\mathrm{i}}, \alpha\right)=\phi\left[\mathrm{h}\left(\mathrm{w}_{\mathrm{i}}, \alpha\right)\right]+\varepsilon_{\mathrm{i}}
$$

where, $Z_{\mathrm{i}}$ is an indicator variable equal to unity for households that own livestock; $\phi$ is the standard normal cumulative distribution function; $\mathrm{w}$ is a vector of factors affecting market participation; $\alpha$ is a vector of coefficients to be estimated, and $\varepsilon_{\mathrm{i}}$ is the error term assumed to be distributed normally with a mean of zero and a variance $\sigma^{2}$.

The variable $Z_{i}$ takes the value of 1 if the marginal utility the $i^{\text {th }}$ household gets from participating in the market is greater than zero, and zero otherwise. So we have:

$$
\mathrm{Z}_{\mathrm{i}}^{*}=\alpha \mathrm{w}_{\mathrm{i}}+\mathrm{v}_{\mathrm{i}}
$$

where, $\mathrm{Zi}^{*}$ is the latent level of utility the household gets from dairy cow ownership (i.e., market participation) $\mathrm{vi} \sim \mathrm{N}(0,1)$

and,

$$
\begin{aligned}
& Z_{\mathrm{i}}=1, \text { if } \mathrm{Z}_{\mathrm{i}}^{*}>0 \\
& \mathrm{Z}_{\mathrm{i}}=0, \text { if } \mathrm{Z}_{\mathrm{i}}^{*}<0
\end{aligned}
$$

The second step involved identification of determinants of milk volume sold conditional on dairy cow ownership. In this step, the inverse of mills ratio (IMR) was added as a regressor in the sales volume function regarding level of participation in order to correct for potential selection bias if only the households which owned dairy cows were included in the second step. The IMR is computed according to (Heckman, 1979)

$$
\lambda=\phi\left[\mathrm{h}\left(\mathrm{w}_{\mathrm{i}}, \alpha\right)\right] / \Phi\left[\mathrm{h}\left(\mathrm{w}_{\mathrm{i}}, \alpha\right)\right]
$$

where, $\phi($.$) is the normal probability density function and \Phi($.$) is the normal cumulative probability density$ function. The second-stage (sales) equation is then given by:

$$
\mathrm{E}(\mathrm{Y} / \mathrm{Z}=1)=\mathrm{f}\left(\mathrm{x}_{\mathrm{i}}, \beta\right)+\gamma \phi\left[\mathrm{h}\left(\mathrm{w}_{\mathrm{i}}, \alpha\right)\right] / \Phi\left(\mathrm{w}_{\mathrm{i}}, \alpha\right)
$$

where, $\mathrm{E}$ is the expectation operator, $\mathrm{Y}$ is the (continuous) extent of market participation, or sales, $\mathrm{x}$ is a vector of independent variables affecting sales, and $\beta$ is the vector of the corresponding coefficients to be estimated.

So $\mathrm{Y}_{\mathrm{i}}$ is expressed as:

$$
\mathrm{Y}_{\mathrm{i}}^{*}=\beta^{\prime} \mathrm{x}_{\mathrm{i}}+\gamma \lambda+\mathrm{u}_{\mathrm{i}}
$$

where, $\mathrm{u}_{\mathrm{i}} \sim \mathrm{N}\left(0, \sigma_{\mathrm{u}}\right) ; \mathrm{Y}_{\mathrm{i}}^{*}=$ is only observed for dairy cow owners $\left(\mathrm{Z}_{\mathrm{i}}=1\right)$, in which case $\mathrm{Y}_{\mathrm{i}}^{*}=\mathrm{Y}_{\mathrm{i}}$ estimated by full maximum likelihood using the Heckman procedure in STATA.

\subsection{Analytical Framework}

The hypothesis under this study was that socio economic factors had no influence on households' decisions on market participation. 


\subsubsection{Variable Description}

Table 1. Variable description for dairy cow ownership

\begin{tabular}{|c|c|c|c|}
\hline Variable name & Type & Description & Expected Priori relationship \\
\hline \multicolumn{4}{|l|}{ Dependent Variable } \\
\hline Dairy cow ownership & $\mathrm{D}$ & Dummy variable of whether or not a household owns dairy cow & - \\
\hline \multicolumn{4}{|l|}{ Independent variables } \\
\hline Age of household head & $\mathrm{C}$ & Age of the household head in years & $+\mathrm{ve}$ \\
\hline Gender of household head & $\mathrm{D}$ & Sex of household head & + ve or -ve \\
\hline $\begin{array}{l}\text { Awareness of community } \\
\text { milk cooling plant }\end{array}$ & $\mathrm{D}$ & Whether a producer is aware of community milk cooling plant & $+\mathrm{ve}$ \\
\hline Household size & $\mathrm{C}$ & Number of family members staying together & $+\mathrm{ve}$ \\
\hline Education level & $\mathrm{C}$ & Years of schooling of household head & $+\mathrm{ve}$ \\
\hline Value of household assets & $\mathrm{C}$ & $\begin{array}{l}\text { Total value in Ksh of refrigerators, TV, radio and others owned } \\
\text { by the household }\end{array}$ & $+\mathrm{ve}$ \\
\hline Land size & $\mathrm{C}$ & Total size of land owned by the household for farming in acres & + ve or -ve \\
\hline Price per litre of milk & $\mathrm{C}$ & Open market price per liter in Ksh & $+\mathrm{ve}$ \\
\hline Distance to market centre & $\mathrm{C}$ & $\begin{array}{l}\text { Distance from agricultural households to main market } \\
\text { centre in kilometres }\end{array}$ & $-\mathrm{ve}$ or $+\mathrm{ve}$ \\
\hline
\end{tabular}

Note $. \mathrm{D}=$ Discrete variable, $\mathrm{C}=$ Continuous variable, $\mathrm{Ksh}=$ Kenya shilling.

The variables described in Table 1 were used in the first step involving the use of a probit model on choice model of dairy cow ownership.

Table 2. Variable description for net milk sales

\begin{tabular}{|c|c|c|c|}
\hline Variable name & Type & Description & Expected Priori relationship \\
\hline \multicolumn{4}{|l|}{ Dependent variable } \\
\hline Quantity sold & $\mathrm{C}$ & Volume of milk sold in litre & \\
\hline \multicolumn{4}{|l|}{ Independent variable } \\
\hline Gender of household head & $\mathrm{D}$ & Sex of household head & -ve or + ve \\
\hline Age of Household head & $\mathrm{C}$ & Age of the household head in years & $+\mathrm{ve}$ \\
\hline Household size & $\mathrm{C}$ & Number of people living in the household & $+\mathrm{Ve}$ \\
\hline Education level & $\mathrm{C}$ & Years of schooling of household head & $+\mathrm{ve}$ \\
\hline Value of household assets & $\mathrm{C}$ & $\begin{array}{l}\text { Total value in Ksh of refrigerators, TV, radio owned by the } \\
\text { household, sofa set, bicycle and others }\end{array}$ & $-\mathrm{Ve}$ \\
\hline Number of dairy cows & $\mathrm{C}$ & Number of milk cows in the herd & $+\mathrm{ve}$ \\
\hline Fresh milk price per litre & $\mathrm{C}$ & Open market price in Ksh per litre & $+\mathrm{ve}$ \\
\hline Distance to main market centre & $\mathrm{C}$ & $\begin{array}{l}\text { Distance from agricultural households to the main market } \\
\text { centre in kilometers }\end{array}$ & -ve \\
\hline
\end{tabular}

Note. $\mathrm{D}=$ Discrete variable, $\mathrm{C}=$ Continuous variable, $\mathrm{Ksh}=$ Kenya shilling.

The variables described in Table 2 were used in the second step which involved identification of determinants of milk volume sales conditional on dairy cow ownership where the inverse of mills ratio (IMR) was added as a regressor.

\section{Results}

Before running the Heckman two stage model, the variables were checked for existence of multicollinearity and heteroscedasticity problems. A technique of Variance Inflation Factor (VIF) and Huber White Test were used to detect the problem of multicollinearity and heteroscedasticity respectively among exogenous variables. 
Table 3. Multicollinearity test results for the explanatory variables

\begin{tabular}{lll}
\hline \multirow{2}{*}{ Variable } & \multicolumn{2}{c}{ Collinearity Statistics } \\
\cline { 2 - 3 } & Tolerance & VIF \\
\hline Gender of household head & .941 & 1.063 \\
Age of household head & .931 & 1.074 \\
Fresh milk price per litre in open market & .909 & 1.101 \\
Education level in years & .876 & 1.142 \\
Household size & .964 & 1.037 \\
Value of household asset in (Ksh) & .857 & 1.165 \\
Number of dairy cows & 0.904 & 1.107 \\
Distance to market centre & 0.885 & 1.130 \\
\hline
\end{tabular}

Note. VIF = Variance Inflation Factor.

The VIF result in Table 3 showed that the data had no problem of multicollinearity. This was because for all exogenous variables, the values of VIF were less than the upper limit of 10 . The heteroscedasticity test P-value was 0.1337 and was insignificant implying that there was no problem of heteroscedasticity.

Table 4. Probit and marginal effect output of analysis of factors affecting dairy cow ownership

\begin{tabular}{lllll}
\hline Variable & Coefficient & $\{\mathrm{P}>\mathrm{Z}\}$ & Marginal effect $(\mathrm{dy} / \mathrm{dx})$ & $\mathrm{P}>[\mathrm{Z}]$ \\
\hline Household size & 0.0803383 & $0.002^{* * *}$ & 0.0320487 & $0.002^{* * *}$ \\
Age of household head & 0.0084341 & $0.063^{*}$ & 0.0033646 & $0.063^{*}$ \\
Education years of household head & 0.0662716 & $0.005^{* * *}$ & 0.0264372 & $0.005^{* * *}$ \\
Value of household assets & $3.78 \mathrm{e}-06$ & $0.080^{*}$ & $1.51 \mathrm{e}-06$ & $0.080^{*}$ \\
Land size in acres owned & 0.0720103 & $0.018^{* *}$ & 0.0287265 & $0.018^{* *}$ \\
Gender of household head & -.1275916 & 0.381 & -0.0508048 & 0.381 \\
Awareness of community milk cooler & 0.951202 & 0.527 & 0.0379456 & 0.527 \\
Distance to main market centre & 0.0018053 & 0.884 & 0.0007202 & 0.884 \\
Fresh milk price per litre open market & 0.002563 & 0.676 & 0.0010224 & 0.676 \\
\hline
\end{tabular}

Note. Number of Observations $=543, \mathrm{LR} \mathrm{chi}^{2}(9)=44.59 \mathrm{Prob}>\mathrm{chi}^{2}=0.0000$, Log likelihood $=-354.07522$, Pseudo $\mathrm{R}^{2}=0.0592 . * * * * *$ and $*$ indicate statistical significance at $1 \%, 5 \%$ and $10 \%$ respectively.

The results of the probit regression (Table 4) showed that household size, level of education and land size had statistically significant and positive influence on the decision to own a dairy cow at $(\mathrm{p}<0.05)$ significance level. For better interpretation of how socio economic factors influenced dairy cow ownership, marginal effects were generated and incorporated in Table 4. From the output, the computed marginal effects at the means for household size, level of education in years and land acreage owned were $0.0320487,0.0264372$ and 0.0287265 respectively. This implied that if each of the mentioned variables increased by small number, then probability of owning a dairy cow would increase by that small number multiplied by the marginal effects value. The age of household head and value of assets were not statistically significant at $(\mathrm{p}<0.05)$ but were significant at $(\mathrm{p}<0.1)$. The computed marginal effects at the means for the age of household head and the value of assets of a household were 0.0033646 and $1.51 \mathrm{e}-06$ respectively. This meant that if age of household head and the value of assets of a household increased by a small number, then probability of owning a cow would increase by that small number multiplied by the marginal effects value.

Through a single command in STATA, the Heckman two stage regression model was run with a focus on the milk volume sold model estimates conditional on dairy cow ownership. 
Table 5. Heckman selection regression model output for market participation

\begin{tabular}{|c|c|c|c|}
\hline Quantity sold & Coefficient & $\mathrm{Z}$ & $\mathrm{P}>[\mathrm{z}]$ \\
\hline \multicolumn{4}{|l|}{ Quantity sold } \\
\hline Age of household head & -0.0150329 & -1.05 & 0.292 \\
\hline Education years of household head & 0.0958395 & 1.12 & 0.262 \\
\hline Value of household assets & $9.02 \mathrm{e}-06$ & 1.45 & 0.146 \\
\hline Gender of household & 0.0485545 & 0.15 & 0.883 \\
\hline Household size & -0.2178241 & -2.46 & $0.014^{* * *}$ \\
\hline Distance to main market & 0.0320533 & 1.22 & 0.224 \\
\hline Fresh milk Price open market in Ksh & -0.0102864 & -1.00 & 0.319 \\
\hline Number dairy cows & 0.354404 & 4.71 & $0.000 * * *$ \\
\hline -Cons & 4.663656 & 1.55 & 0.121 \\
\hline \multicolumn{4}{|l|}{ Select } \\
\hline Age of Household head & 0.0084341 & 1.86 & $0.063^{*}$ \\
\hline Education years of household head & 0.0662716 & 2.8 & $0.005 * * *$ \\
\hline Value of household assets & $3.78 \mathrm{e}-06$ & 1.75 & $0.080^{*}$ \\
\hline Land size owned by household & 0.0720103 & 2.38 & $0.018^{* *}$ \\
\hline Gender of household head & -0.1275916 & -.88 & 0.381 \\
\hline Awareness of community cooler & 0.0951202 & 0.63 & 0.527 \\
\hline Household size & 0.0803383 & 3.11 & $0.002 * * *$ \\
\hline Distance to main market & 0.0018053 & 0.15 & 0.884 \\
\hline Fresh milk price open market & 0.002563 & 0.42 & 0.676 \\
\hline -Cons & -1.938801 & -4.15 & $0.000 * * *$ \\
\hline \multicolumn{4}{|l|}{ Mills } \\
\hline Lambda & -0.6339829 & -0.45 & 0.655 \\
\hline Rho & -0.32025 & & \\
\hline Sigma & 1.9796796 & & \\
\hline
\end{tabular}

Note. Number of observations $(\mathrm{Obs})=543$, Censored obs $=270$, Uncensored obs $=273$, Wald $\operatorname{chi}^{2}(8)=66.18$, Prob. $>$ chi $^{2}=0.0000, * * *, * *$ and $*$ indicate statistical significance at $1 \%, 5 \%$ and $10 \%$ respectively.

The results in Table 5 on determinants of milk volume sold showed that household size and number of dairy cows were statistically significant at $(\mathrm{P}<0.05)$. Within the same table, a lambda value was generated which was used to compute the average truncation effect. Since selection and outcome model had residuals for each observation, the relationship between the residuals of the two models was examined through rho value which was the correlation coefficient between the residuals. In this study rho value was -0.32025 and its chi square value was statistically significant meaning that biased estimates would be obtained if not corrected. The negative sign indicated that unobservables between the adoption of dairy cow and quantity of milk sold by households were negatively correlated. This implied that in the determinants of quantity of milk sold model, there was unobserved variable that was negatively related to adoption of dairy cow but was positively related to quantity of milk sold.

The sigma value gave the adjusted standard error for the quantity of milk sold regression equation and the value was 1.9796796 while Lambda $=$ sigma $\times$ rho $=1.9796796 \times-0.32025=-0.6339829$ which was the estimated selection coefficient.

For the purpose of quantifying the effect of the selectivity bias, the average truncation effect was computed using the average mills value in table 6 , obtained from a STATA command after the probit regression.

Table 6. Summary of mills

\begin{tabular}{llllll}
\hline Variable & obs & Mean & Std Dev. & Min & Max \\
\hline Mills & 543 & 0.8031949 & 0.1979657 & 0.1679952 & 1.377128 \\
\hline
\end{tabular}

The average truncation effect in this study was computed as lambda $\times$ [average mills value] $=-0.63398286 \times$ $0.8031949=-0.5092118$. This explains by how much the conditional quantity of milk sold was shifted up or down 
due to the selection or truncation effect. The interpretation of this was that a household with sample average characteristics who selects into cow ownership secures $[\exp (-0.5092118)-1] \times 100=-39.90 \%$ lower quantity sold than a household drawn at random from the population with the average set of characteristics. Thus, the numerical value suggested that there was a negative selection or truncation effect. Those who select into dairy cow ownership sell lower volumes of milk than a random drawing from the population of households with a comparable set of characteristics would sell so long as there was a statistically significant effect of selection or the chi-square value for rho was statistically significant.

\section{Discussion}

From the results, the probability of dairy cow ownership or dairy cow adoption was associated positively and statistically significant at $\mathrm{p}=0.002$ with the household size. According to Baltenweck and Staal (2000), dairying is a labour-intensive activity, therefore larger household sizes translate to labour availability which is expected to foster adoption. In explaining dairy cattle adoption behavior amongst smallholders in Kenya, Abayomi (2013) found that the number of boys positively influenced ownership of dairy cows. This was because of the labour that boys offered especially on fodder search. In Tanzania Kaliba, Featherstone, and Norman (1997) also found a positive correlation between cattle stall-feeding and availability of male children in the household. In other livestock based technologies, Teklewold, Dadi, Yami, and Dana (2006) in Ethiopia, found that household size positively influenced ownership of exotic poultry breeds.

The level of education as measured by the number of years in school was also positively related and statistically significant at $(\mathrm{p}=0.005)$ with probability of owning a dairy cow. This finding was in agreement with the finding of Quddu (2013) which stated that adoption of technology was positively associated with level of farmers' education. As Berem, Obare, and Bett (2015) observed, education plays a role in adoption of new technologies and is believed to improve readiness of a household head to accept new innovations. Studies by Huffman (1977) in Iowa State, America had earlier found that higher levels of farm operator education were likely to induce adoption of new technology. Baltenweck and Staal (2000) also agree that education level plays a positive role in the adoption decision but adds that older household heads tend to adopt less, because of possible higher risk-aversion.

The size of land parcel owned by the producers in acres was associated positively and significantly $(\mathrm{p}=0.018)$ with probability of dairy cow ownership. According to Baltenweck and Staal (2000), farmers with large land size adopt faster, reflecting higher savings from crop activities as well as greater potential for growing fodder. In their study on reducing poverty through investments in water and other priorities in sub-Saharan Africa, Hanjra, Ferede, and Gutta (2009) seemed to support this position when they observed that farmers with larger landholdings invested in land and water management practices. This was attributed to larger land holdings having greater wealth and increased availability of capital. The finding in this study differs with Dehinenet, Mekonnen, Kidoido, and Bleich (2014) who found out that land was not significantly associated with adoption of new dairy technology. Makokha, Karugia, and Kosura (2007) in their findings of factors influencing adoption of dairy technologies in Western Kenya found that a decrease in land size was associated with an increase in the probability of adopting improved dairy breeds. This negative relationship was explained by the fact that technologies that increase returns to land are adopted only when factor proportions are constrained. Thus, efforts to increase returns to land, the constrained factor relative to the other resources, were made through adoption of improved dairy breeds. In areas where dairy production is predominantly free range like observed in this study, in Western Kenya, large land for forage production or grazing would be required.

With respect to milk sales determinants, the main factor influencing quantity of milk sold was household size and number of dairy cows owned. Household size had a negative and significant $(p=0.014)$ relationship with the quantity of milk sold by households. This finding was in line with Kuma, Baker, Getnet, and Kassa (2013) in their study of factors affecting milk market participation in Ethiopia who explained that, the larger the household size, the more volume of milk required for domestic consumption and the lesser amounts availed for markets. The findings made by Heltberg and Tarp (2002) in their study in Mozambique on Agricultural supply response and poverty showed household dependency ratio did not have significant influence on sales of crop produce. Number of dairy cows had a positive and statistically significant $(\mathrm{p}=0.000)$ relationship with the quantity of milk sold by households. Mutura, Nyairo, Mwangi, and Wambugu (2015) observed that increase in output per day increased probability of choice of cooperatives which take large volumes of milk as a way of lowering transaction cost by avoiding excess milk spoilage. 


\section{Conclusion}

Market participation was defined in terms of dairy ownership and milk volume sold. Higher household sizes and education levels among households positively influenced adoption of dairy cows. Similarly those with larger pieces of land had a higher probability of owning dairy cows. The policy implications of the findings in this study support the promotion of labour and land saving technologies for dairy cow keeping uptake among labour and land resource constrained households. Whereas higher number of dairy cows owned by households boosted milk sales volumes, having larger household sizes influenced negatively net milk sold. It was further noted from the selectivity bias effect that households that selected into cow ownership sold less milk by $39.9 \%$ compared to what households drawn at random from the population with the average set of characteristics would sell. This implied that with appropriate policy interventions that encourage production and marketing, there is great potential for milk sales around the community milk cooling plants.

\section{Acknowledgements}

Authors are grateful to the former Western Kenya Community Driven Development and Flood Mitigation Project staff and the management of the community milk cooling plants studied for their cooperation, information and support during data collection period. The help of enumerators in each community milk cooling plant area is gratefully acknowledged.

\section{References}

Abayomi, S. O. (2013). Factors Explaining Dairy Cattle Adoption Behavior Among Smallholder Farmers in Kenya. Asian Journal of Animal and Veterinary Advances, 8(7)893-903. https://doi.org/10.3923/ajava.2013. 893.903

Baltenweck, I., \& Staal, S. J. (2000). Determinants of adoption of dairy cattle technology in the Kenyan highlands: A spatial and dynamic approach. Contributed Paper Submission, August 13-18, 2000, International Association of Agricultural Economists Meetings, Berlin.

Bellemare, M. F., \& Barret, C. B. (2006). An Ordered Tobit Model of Market Participation.Evidence from Kenya and Ethiopia. American Journal of Agricultural Economics, 88(2), 324-327. https://doi.org/10.1111/ j.1467-8276.2006.00861.x

Berem, M. R., Obare, G., \& Bett, H. (2015). Analysis of Factors Influencing Choice of Milk Marketing Channels among Dairy Value Chain Actors in Peri-urban Areas of Nakuru County, Kenya. European Journal of Business and Management, 7(28).

Dehinenet, G., Mekonnen, H., Kidoido, M. A., \& Bleich, G. (2014). Factors Influencing Adoption of Dairy Technology on Smallholder Dairy Farmers in Selected Zones of Amhara and Oromia National Regional States, Ethiopia. Discourse Journal of Agriculture and Food Sciences, 2(5), 124-135.

Goetz, S. (1992). A Selectivity Model of Household Food Marketing Behaviour in Sub-Saharan Africa. American Journal of Agricultural Economics, 72(2), 444-452. https://doi.org/10.2307/1242498

Government of Kenya. (2008). Sessional paper on national livestock policy. Nairobi: Government Printers.

Government of Kenya. (2014). Government of Kenya economic survey report 2014. Nairobi.

Hanjra, A., Ferede, T., \& Gutta, D. (2009). Pathways to Breaking the Trap in Ethopia: Investments in agricultural water, education and markets. Agricultural Water Management, 96(11), 1596-1604. https://doi.org/10.1016/ j.agwat.2009.06.008

Heckman, J. (1979). Sample Selection Biase as a Specification Error. Econometrica, 47(1), 153-161. https://doi.org/10.2307/1912352

Heltberg, R., \& Tarp, F. (2002). Agricultural Supply Response and Poverty in Mozambique. Food Policy, 27(2), 103-124. https://doi.org/10.1016/S0306-9192(02)00006-4

Holloway, G., Barret, C., \& Ehui, S. (2001). The double hurdle model in the presence of fixed costs. Ssrn Electronic Journal, 1(1).

Huffman, W. E. (1977). Allocative Efficiency: The Role of Human Capital. Quarterly Journal of Economics, 91(February), 59-79. https://doi.org/10.2307/1883138

Kaliba, A., Featherstone, A. M., \& Norman, D. W. (1997). A Stall-Feeding Management for Improved Cattle in Semiarid Central Tanzania: Factors influencing adoption. Agricultural Economics, 17(2-3), 133-146. https://doi.org/10.1016/S0169-5150(97)00028-5 
Kenya Dairy Board. (2012). Milk production. Retrieved from http://www.kdb.co.ke/contact/milk production

Kothari, C. R. (2004). Research Methodology: Methods and Techniques (2nd ed.). New Age International Publishers.

Kuma, B., Baker, D., Getnet, K., \& Kassa, B. (2013). Factors Affecting Milk Outlet Choices in Wolaita Zone, Ethiopia. African Journal of Agricultural Research, 8(21), 2493-2591.

Makokha, S. N., Karugia, J., Staal, S., \& Kosura, O. (2007). Analysis of factors influencing adoption of dairy technologies in western Kenya (pp. 209-213). Conference Proceedings, August 20-22, 2007, African Association of Agricultural Economists, Accra, Ghana.

Muriuki, H., Omore, A., Hooton, N., Waithaka, M., Ouma, R., \& Staal, S. (2004). The policy environment subsector in Kenya: A review of smallholder dairy project. Nairobi: Regal Press.

Mutura, K. J., Nyairo, N., Mwangi, M., \& Wambugu, K. S. (2015). Vertical and Horizontal Integration as Determinants of Market Channel Choice among Smallholder Dairy Farmers in Lower Central Kenya. Asian Journal of Economics and Empirical Research, 2(2), 89-90.

Quddus, M. A. (2013). Adoption of Dairy Farming Technologies by Small Farm Holders: Practices and Constraints. Bangladesh Journal Animal Science, 41(2), 124-135. https://doi.org/10.3329/bjas.v41i2.14132

Teklewold, H., Dadi, L., Yami, A., \& Dana, N. (2006). Determinants of Adoption of Poultry Technology: A Double Hurdled Approach. Livestock Research for Rural Development, 18(3), 75-86.

Wambugu, S., Kirimi, L., \& Opiyo, J. (2011). Productivity trends and performance of dairy farming in Kenya. Dairy Productivity Conference (p. 114). Nairobi: Tegemeo Institute.

Wanjala, S., Njehia, B. K., \& Murithi, M. F. (2015). Is the Traditional Role of Milk Cooperatives Still Relevant? Evidence from Western Kenya. Asian Journal of Agricultural Extension, Economics and Sociology, 6(4), 202-208. https://doi.org/10.9734/AJAEES/2015/17753

\section{Copyrights}

Copyright for this article is retained by the author(s), with first publication rights granted to the journal.

This is an open-access article distributed under the terms and conditions of the Creative Commons Attribution license (http://creativecommons.org/licenses/by/4.0/). 